\title{
Production of biogas from anaerobic digestion of poultry droppings and domestic waste using catalytic effect of silica gel
}

\author{
J.U. Ahamed ${ }^{1 *}$, M.F. Raiyan', MD. S. Hossain', M.M. Rahman² and B. Salam ${ }^{1}$ \\ ${ }^{1}$ Department of Mechanical Engineering, Chittagong University of Engineering and \\ Technology, Chittagong-4349, Bangladesh \\ 1*Phone: +8801720-641636, +88031-714935; Fax: +88031-714910 \\ *Email: jamal293@yahoo.com \\ ${ }^{2}$ Faculty of Mechanical Engineering, Universiti Malaysia Pahang, \\ 26600 Pekan, Pahang, Malaysia \\ Email: mustafizur@ump.edu.my
}

\begin{abstract}
This research work has been performed to produce biogas from poultry and household (kitchen) waste using silica gel as a catalyst. A fabricated laboratory scale digester was used to generate biogas from the locally available waste obtained from poultry farms and domestic kitchens. Two laboratory-scale digesters were prepared to digest the solid wastes with and without silica gel respectively. The operating temperatures of the digesters were maintained within $26^{\circ} \mathrm{C}-31^{\circ} \mathrm{C}$. The water displacement method was used to investigate the volume of the produced gas. It was found that the production rate of biogas was increased while using silica gel as catalyst. The total gas production was found to be $7921 \mathrm{ml} / \mathrm{kg}$ of waste without silica gel whereas it was $10545 \mathrm{ml} / \mathrm{kg}$ with a maximum production rate of $1206 \mathrm{ml} / \mathrm{kg}$ in a day with silica gel as a catalyst and it was $33.12 \%$ higher than before. Finally, by using a k-type thermocouple, the flame temperature of the gas was measured as $619^{\circ} \mathrm{C}$. Considering the magnitude of flame temperature and total gas yield after adding the silica gel, the large scale set-ups can be a prospective source of clean energy.
\end{abstract}

Keywords: Biogas; Anaerobic digestion; Poultry waste; Silica gel; Flame temperature

\section{INTRODUCTION}

Biogas is a mixture of methane and carbon dioxide produced by the breakdown of organic waste by bacteria. Biogas is a by-product of the biological breakdown under the oxygenfree conditions of organic wastes such as plants, crop residues, fish residues, wood and bark residues, and human and animal manure [1]. Biogas which is produced when bacteria decompose organic material such as garbage and sewage is a mixture of about 60 percent methane and 40 percent carbon dioxide [2]. Methane is the main component of natural gas which is relatively clean burning, colourless, and odourless [3-6]. This gas can be captured and burned for cooking and heating that are being done on a large scale in some countries of the world. Gas production is enhanced with the use of methane starters. Under optimum conditions which are the pretreatment dilution, $\mathrm{pH}$, agitation, light intensity and an addition of actizyme, maximum gas production can be obtained after 30 days of 
anaerobic fermentation [7]. The energy scenario of Bangladesh is dominated by traditional energy sources that supply about 64 percent of the total energy consumption. The scarcity of the costly fossil fuels has already become a burning issue. Moreover, as a result of deforestation, there is a scarcity of fuel wood in some parts of our country. As most of the people largely depend on it, there is a need to look for an alternative fuel. In this prospect, biogas can be a great alternative source of energy in our country because it can be produced from the locally available waste materials such as cow dung, chicken droppings, fish waste, aquatic weed, vegetable waste, residues from domestic cooking etc. [8]. Thus, in this regard a biogas generating model has been fabricated to produce biogas from the anaerobic digestion of chicken droppings and kitchen wastes to analyse its feasibility for practical purpose. Silica gel was also used as a catalyst to increase the gas production [9]. Silica gel was chosen as a catalyst because of its cheapness and availability. According to a previous study [10], silica gel acts as a good catalyst for biogas production because the catalytic and absorbing effects of silica gel are used for the removal of undesired gases such as $\mathrm{CO}_{2}$.

The anaerobic digestion is a renewable energy source because the process produces a methane and carbon dioxide rich biogas suitable for energy production which helps to replace fossil fuels. Also, the nutrient-rich solids left after digestion can be used as fertilizers [11]. Various research woks were performed to investigate the feasibility of biogas production and application. Along with personal, institutional and government projects all over the world, scholarly articles were also published based on projects and data collection. Abubakar and Ismail [12] performed an anaerobic digestion of cow dung. The average cumulative biogas yield and methane content observed was $0.15 \mathrm{~L} / \mathrm{kg}$ of VS (volatile solid) and 47\%, respectively. Their study established that cow dung is an effective feedstock for biogas production. Ghani and Idris [13] concluded a study on biogas production from municipal waste. They carried their experiment using the low and high strength chemical oxygen alongside municipal waste. From their study, they established that there is a potentiality of biogas production from the municipal waste leachate. The effects of loading rate, temperature, stirrer, both single and co-digestion of feedstock on biogas function and energy efficiency ratio were examined by utilizing an industrial-scale anaerobic digester with the retention time of 12 days [14]. They used cow and poultry manure for biogas production. Tests were performed in 24 various treatments. The results gained from feeding the digester with cow dung in $35^{\circ} \mathrm{C}$ through different loading rates with and without stirrer showed that the highest rate of biogas was developed in the loading rate of $1 / 4$ along with a stirrer. Likewise, the results gained from various feeding processes with the loading rate of $1 / 4$ showed that the highest biogas amount produced was by treatment $\mathrm{I} 2\left(36-40^{\circ} \mathrm{C}\right.$, with the stirrer) with about $950 \mathrm{lit} / \mathrm{day}$, and most efficient energy rate was developed through treatment $\mathrm{J} 2\left(36-40^{\circ} \mathrm{C}\right.$, with the stirrer) with about 3.9 MJ.

Agrahari and Tiwari [15] investigated the production of biogas from kitchen wastes. They analysed different ratios of kitchen waste in a metal made portable floating type biogas plant. In their study, the temperature, solar radiation and relative humidity have been measured. They also analysed the constituent of biogas, $\mathrm{pH}$, volume and rate of biogas production at different level of temperature observation on daily basis. Desai and Madamwar [16] performed an anaerobic digestion of a mixture of cheese whey, poultry waste and cattle dung. They used various adsorbents to improve the digester performance. The adsorbents appeared to improve the digester performance, for example about a two-fold enhancement in total gas production with $17 \%$ enriched methane content were achieved with the addition of $4 \mathrm{~g}$ litre $(-1)$ of silica gel. An experiment was done 
regarding the production of biogas from the municipal solid wastes with domestic sewage by using anaerobic digestion process [17]. The enhancement of the biogas production was done by adding domestic sewage to the municipal wastes. In that experiment, they succeeded to produce biogas having the quality of $68 \%-72 \%$. Isci and Demirer [18] analysed the potentiality of biogas production from cotton wastes. They performed biochemical methane potential experiments for two different waste concentrations which are $30 \mathrm{~g} / \mathrm{l}$ and $60 \mathrm{~g} / \mathrm{l}$. The results showed that cotton wastes can be treated anaerobically and an effective source of biogas. Karim, Hoffmann [19] showed that the unmixed and mixed digesters performed quite similarly when fed with $5 \%$ manure slurry and produced biogas at a rate of 0.84-0.94 L/d. The methane yield was found to be $0.26-0.28 \mathrm{~L} \mathrm{CH} 4 / \mathrm{g}$ loaded with volatile solid. They performed their experiment at a controlled temperature of $35^{\circ} \mathrm{C}$ and hydraulic retention time of 16.2 days, resulting in TS loadings of 3.1, 6.2, and $9.3 \mathrm{~g} / \mathrm{L} \mathrm{d}$ for $5 \%, 10 \%$, and $15 \%$ manure slurry feeds, respectively. An experiment on biogas production from water hyacinth was conducted by Kunatsa [20]. From their experiment, they obtained the biogas yield of $1681.08 \mathrm{~m}^{3} /$ day. It was also established that using the dry water hyacinth would produce more biogas in comparison to the fresh water hyacinth. Li, Chen [21] observed the anaerobic co-digestion for biogas production. Kitchen wastes were used with cattle manure for their research purpose. Biogas production using batch anaerobic digesters at the mesophilic and thermophilic temperatures was also studied [22]. Researchers performed the thermophilic digestion test with four different feeds to inoculum ratios and the mesophilic digestion was conducted at one feed to inoculum ratio $(3: 1)$. The results showed that the feed to inoculum ratio significantly affected the biogas production rate. In their experiment, $80 \%$ of the biogas production was obtained during the first 10 days of digestion. They obtained the biogas yields as 430, 372 and $358 \mathrm{~mL} / \mathrm{g}$ VS (volatile solids), whereas the methane yields were 245,206 , and $185 \mathrm{~mL} / \mathrm{g}$ VS. [23] studied on batch and continuous biogas production from animal wastes. Both processes were conducted within the mesophilic temperature ranges. In their setup, they found that maximum biogas yield were 3.603 and 2.685 litres in the continuous process and batch process at a temperature of $370^{\circ} \mathrm{C}$ and $400^{\circ} \mathrm{C}$ respectively. Biogas production using rice husk has also been performed [24]. It was studied on different parameters like water dilution, initial $\mathrm{pH}$, heavy metals and nitrogen sources on digester performance. Biogas was produced at a rate of $30 \mathrm{~mL} /$ day and $69 \mathrm{~mL} /$ day for the control and poultry droppings, respectively, after two days while urea gave $8 \mathrm{~mL} /$ day on day four. They used poultry droppings (PD) as nitrogen supplements. In the study, they established that rice husk offers an alternative source of energy to agricultural farmers.

Otaraku and Ogedengbe [25] conducted an experiment to produce biogas from sawdust, co-digested with cow dung and water hyacinth. They produced biogas at a rate of 0.045 litres/s fed when about $11.48 \mathrm{gm}$ of sawdust waste was digested in a fixed amount of cow dung and water hyacinth of $7 \mathrm{gm}$. The optimization of biogas production from chicken droppings with cymbopogon citratus was also performed [26]. Chicken droppings were carried out for a period of 30 days at an average ambient temperature of $33.1 \pm 2{ }^{\circ} \mathrm{C}$. They experimented these in identical reactors $(\mathrm{A}-\mathrm{C})$. The result suggested that chicken droppings produced on the average $1.8 \mathrm{~L} / \mathrm{kg} /$ day of biogas, co-digestion of chicken droppings and C. citratus produced $1.3 \mathrm{~L} / \mathrm{kg} /$ day of biogas while C. citratus alone produced $1.0 \mathrm{~L} / \mathrm{kg} /$ day with estimated average methane content of $41.71 \%, 66.20 \%$ and $71.95 \%$ for reactors A-C respectively. Their result suggested that despite the higher biogas volumetric yield from chicken droppings digested alone, the co-digestion of chicken droppings with C. citratus had better gas quality. Quiroga, Castrillón [27] experimented on the effect of ultrasound pre-treatment in the anaerobic co-digestion of 
cattle manure with food waste and sludge. A series of experiments were carried out under the mesophilic and thermophilic conditions in continuously stirred-tank reactors containing $70 \%$ cattle manure, $20 \%$ food waste and $10 \%$ sewage sludge. The ultrasound pre-treatment allows operating at lower HRT, achieving higher volumetric methane yields: $0.85 \mathrm{~L} \mathrm{CH} 4 / \mathrm{L}$ day at $36^{\circ} \mathrm{C}$ and $0.82 \mathrm{CH} 4 / \mathrm{L}$ day at $55^{\circ} \mathrm{C}$, when cattle manure and sewage sludge were sonicated. With respect to the non-sonicated waste, these values represent the increases of up to $31 \%$ and $67 \%$ for the mesophilic and thermophilic digestion, respectively.

A study on a model biogas unit of a breeding farm was made [28]. The anaerobically fermented poultry manure and bovine animal manure were kept in the tank. From the setup, $6.33 \mathrm{~m}^{3}$ and $0.83 \mathrm{~m}^{3}$ biogas was produced from the fermentation of bovine and poultry animal manure respectively. Salam, Biswas [9] used catalyst (silica gel) to produce biogas from the mesophilic anaerobic digestion. They investigated the production ability of biogas from the mesophilic anaerobic digestion of cow dung (CD). The total gas yield was obtained about $27.3 \mathrm{~L} / \mathrm{kg} \mathrm{CD}$ for digestion without catalyst and about $30.5 \mathrm{~L} / \mathrm{kg}$ of CD for digestion with catalyst. Tripathi, Kumari [29] generated biogas using pine needles as substrate. They reduced the pine needles to very fine sizes $(1-2 \mathrm{~mm})$ before co-digesting these with the sewage waste water. It was observed that biogas production peaked from 1.4 liter/day to 1.9 liter/day during winter month, whereas it was 7.3 liter/day during months of March and April. The reduction in the volatile solids was also noticed during the months of March and April which was higher close to 64\% during April compared to its value in winters and cassava peeling using 45 litres biogas digesters. Ukpai and Nnabuchi [30] did a study on the comparative biogas production. They used cow dung, cow pea and cassava peeling in their research with the assistance of 45 litres biogas digesters. The acid property and catalytic activity of silica gel treated with ammonium salts were investigated [31]. The study showed the effect of added ammonium carbonate or sulfate on the acid property of two commercial and a laboratory prepared silica gel. It was found that the treated gels of the high acid strength were catalytically active for the de-polymerization of paraldehyde and the first order rate constant increases with the increase of the acid amount at $\mathrm{H}_{0} \leq-3$ of the gel catalysts. The catalytic activity of the treated and untreated silica gels for the depolymerization of paraldehyde was studied in connection with the acid property.

\section{METHODS AND MATERIALS}

This study is related to the anaerobic digestion of biogas from chicken droppings and kitchen waste. Besides, the effect of silica gel as a catalyst in this experiment has been observed. The raw materials and other relates materials is listed in Table 1.

Table 1. Raw materials and others related data.

\begin{tabular}{ll}
\hline Item & Description \\
\hline Raw materials & Chicken droppings, kitchen waste \\
Fermentation & Continuous anaerobic digestion \\
Digester & Conical flask \\
Gas collection & Water displacement method \\
Catalyst & Silica gel \\
\hline
\end{tabular}


For producing biogas from chicken droppings and kitchen wastes, the anaerobic method was chosen. In this method, the fermentation process takes place about fifteen days. As the research work was done in a small setup laboratory, a conical flask was required. The conical flask contains the required amount of chicken droppings, kitchen wastes, and water. After digestion, the gas was collected by the water displacement method. The whole process was kept air tight. The schematic diagram of the experimental setup is given in Figure 1.

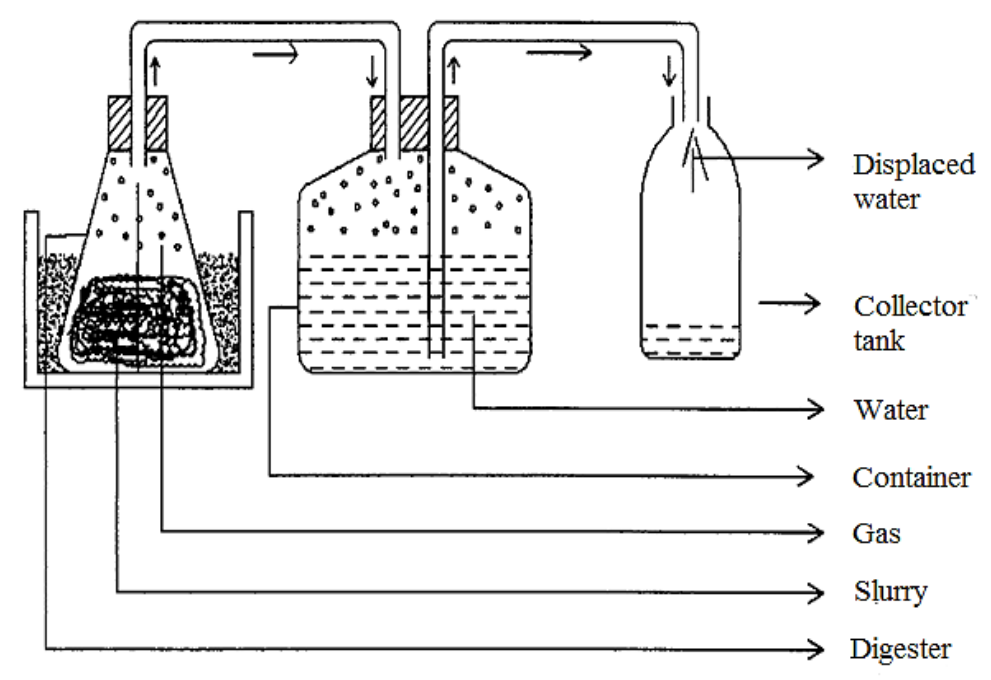

Figure 1. Schematic diagram of the experimental setup.

During the anaerobic digestion, carbohydrates, fats and proteins followed a step by step degradation and finally converted into methane and carbon di-oxide. It involved a four stage process including hydrolysis, acidogenesis, acetogenesis and methanogenesis. The overall process can be described by the chemical reaction where organic material such as glucose is biochemically digested into carbon dioxide $\left(\mathrm{CO}_{2}\right)$ and methane $\left(\mathrm{CH}_{4}\right)$ by the anaerobic microorganisms.

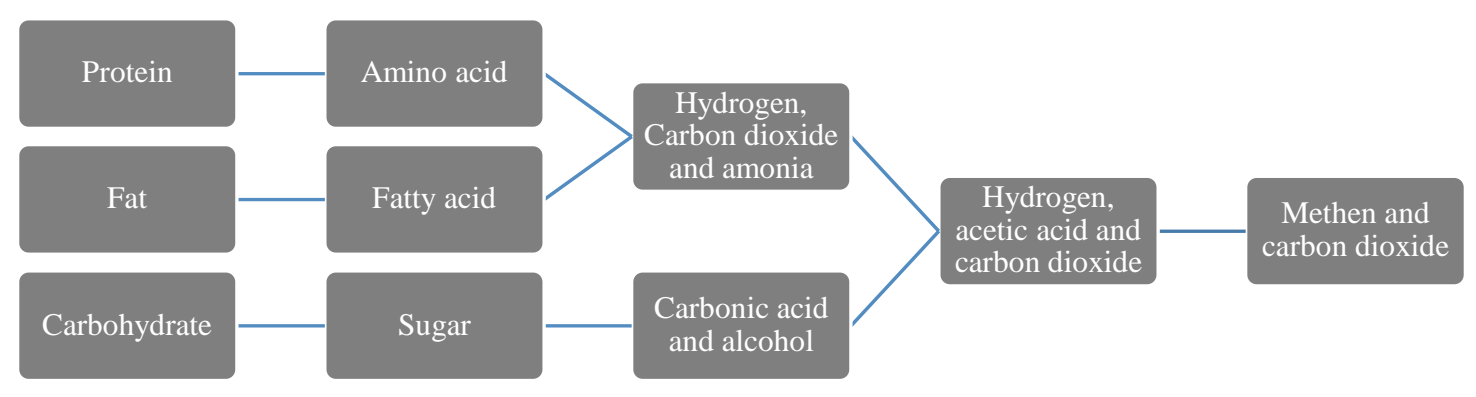

Figure 2. Stages of anaerobic digestion.

The digester was used for processing the slurry. The second and third sections were gas measuring section. Gas production was calculated by using the water displacement method. Many experiments $[9,32,33]$ proved that this method is more effective to measure the volume of the produced gas. The first container contained the waste, which went through the anaerobic digestion process, and the second container containing water 
was displaced by the gas pressure. Figure 3 represents the schematic setup model of the plant.

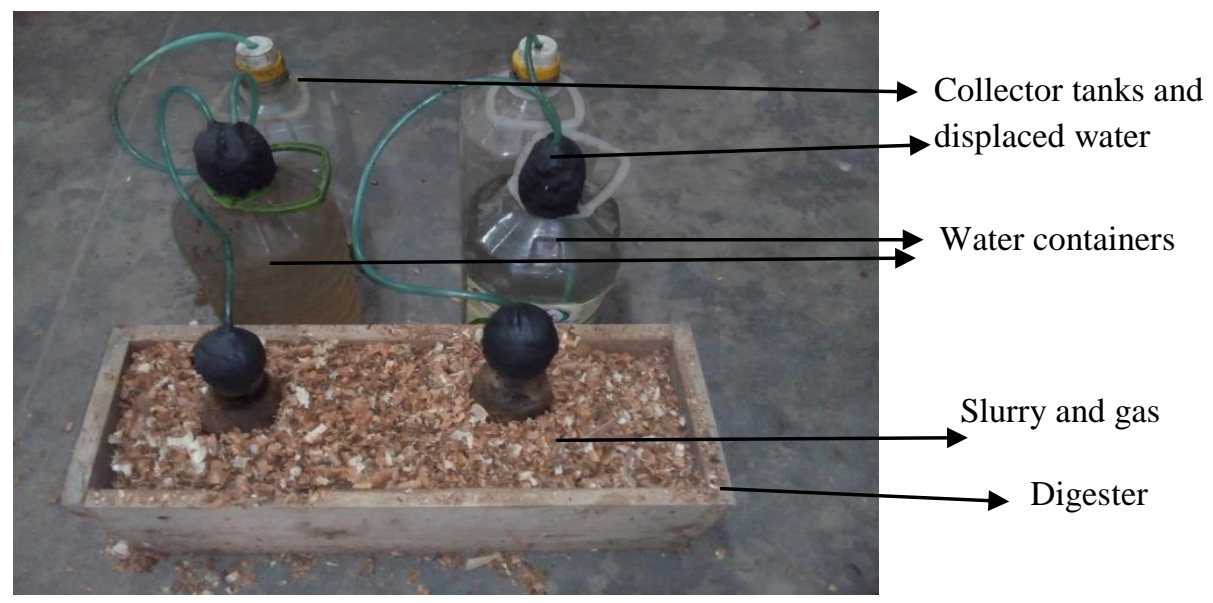

Figure 3. Photograph of the experimental setup.

Thus these two containers were connected by a plastic tube connecting the upper portion of the containers. There was also a pipe connecting the third container with a second one by a plastic tube from the bottom of a water filled container to the upper portion of the third empty container. The total system was completely gas sealed.

\section{Experimental Procedure}

Chicken droppings and kitchen wastes were collected from the local poultry farms and kitchens of student dormitories respectively. Then the total solid contents for the chicken droppings and kitchen wastes were calculated by drying those raw materials. Finally, according to the calculation, the experimental facility was set. Two experimental set-ups were prepared to investigate the production of biogas from the anaerobic digestion of chicken droppings and kitchen wastes, where one set-up was used for the anaerobic digestion with silica gel as catalyst while the other was used for the anaerobic digestion without silica gel. The conical flask contained the waste where the anaerobic digestion process took place and the first container contained water which was displaced by the gas pressure. After setting up the total facility, data collection was initiated. A total amount of $8 \%$ solid for the optimum gas production was chosen. In the slurry, the total solid content (TS) was maintained $8 \%$ (by wt.) for all the observations. It was found that the chicken droppings have a total solid of $32 \%$ and kitchen wastes have a total solid of $18 \%$. Let,

The amount of

$$
\begin{gathered}
\text { Chicken droppings or Kitchen waste }=x \mathrm{gm} \\
\text { The amount of water }=y \mathrm{gm} \\
\text { Slurry }=2 x+y \\
\text { Slurry }=700 \mathrm{gm}
\end{gathered}
$$

Therefore,

$$
\begin{gathered}
700=2 x+y \\
\text { Total solid }=(x \times 0.32+x \times 0.18)
\end{gathered}
$$

Total solid $=8 \%$

Therefore, 


$$
8 / 100=(x \times 0.32+x \times 0.18)
$$

Solving Equations (1) and (2)

$$
\begin{aligned}
& x=160 \mathrm{gm} \\
& y=380 \mathrm{gm}
\end{aligned}
$$

Therefore, the amount of chicken droppings and kitchen wastes were $160 \mathrm{gm}$ (each of them respectively) and the amount of water was $380 \mathrm{gm}$ in the first and second setup. The total solid content of chicken droppings and kitchen wastes was determined by heating them in an oven for $120^{\circ} \mathrm{C}$ for 40 hours. A simple way of evaluating effects on gas production is by comparing the arithmetic means of biogas production in the digester unites with the disintegrated and non-disintegrated substrate [34]. The statistically proper way of comparing means is by applying a statistical test. The daily measured biogas production was considered as a random statistical sample where the independence between the measured data points can be assumed due to the experimental realization. The assumptions regarding normal distribution and homogeneity of variances need to be checked for all experimental data in order to select the suitable statistical test. They can be checked either graphically, numerically with distribution parameters, or with formal preliminary significance tests [34]. All statistical analyses were performed using the oneway analysis of variance (ANOVA). The significance level of 5\% was used throughout the whole analysis and the standard deviation was kept within $\pm 1 \%$. The standard deviations of the total solid and volatile solid determinations were added to the corrected values of the total and volatile solid according to the standard statistical rule $[35,36]$ to provide a standard deviation of the final results.

For linear combinations, the standard deviations were combined according to Equations (3) and (4).

$$
\begin{gathered}
y=k+K_{a} a+K_{b} b+K_{c} c+\cdots \\
\sigma_{y}=\sqrt{\left\{\left(k_{a} \sigma_{a}\right)^{2}+\left(k_{b} \sigma_{b}\right)^{2}+\left(k_{c} \sigma_{c}\right)^{2}+\cdots . .\right\}}
\end{gathered}
$$

For multiplicative applications, the standard deviations are formulated according to Equations (5) and (6).

$$
\begin{gathered}
y=\frac{k a b}{c d} \\
\frac{\sigma_{y}}{y}=\sqrt{\left\{\left(\frac{\sigma_{a}}{a}\right)^{2}+\left(\frac{\sigma_{b}}{b}\right)^{2}+\left(\frac{\sigma_{c}}{c}\right)^{2}+\cdots\right\}}
\end{gathered}
$$

where, $\sigma$ is the standard deviation and a, b, c, and d, are the independently measured quantities and $\mathrm{k}$ is a constant.

\section{RESULTS AND DISCUSSION}

As the data was taken to find the performance in gas production by using the mixture of kitchen waste and poultry droppings, the collected values were used to investigate the outcome of the research project. During the first observation, no silica gel was added and gas production was dependent only on the kitchen wastes and chicken droppings whereas the second setup/observation included additional silica gel along with the original raw waste.

The experimentally obtained data has been used to observe the relation between gas production and number of days. From the first setup, gas production was available only from the raw solid waste without silica gel. The second setup involved the production of 
gas including silica gel. The number of observation days was 32 and during this time span the ambient temperatures varied between $26^{\circ} \mathrm{C}$ and $33^{\circ} \mathrm{C}$.

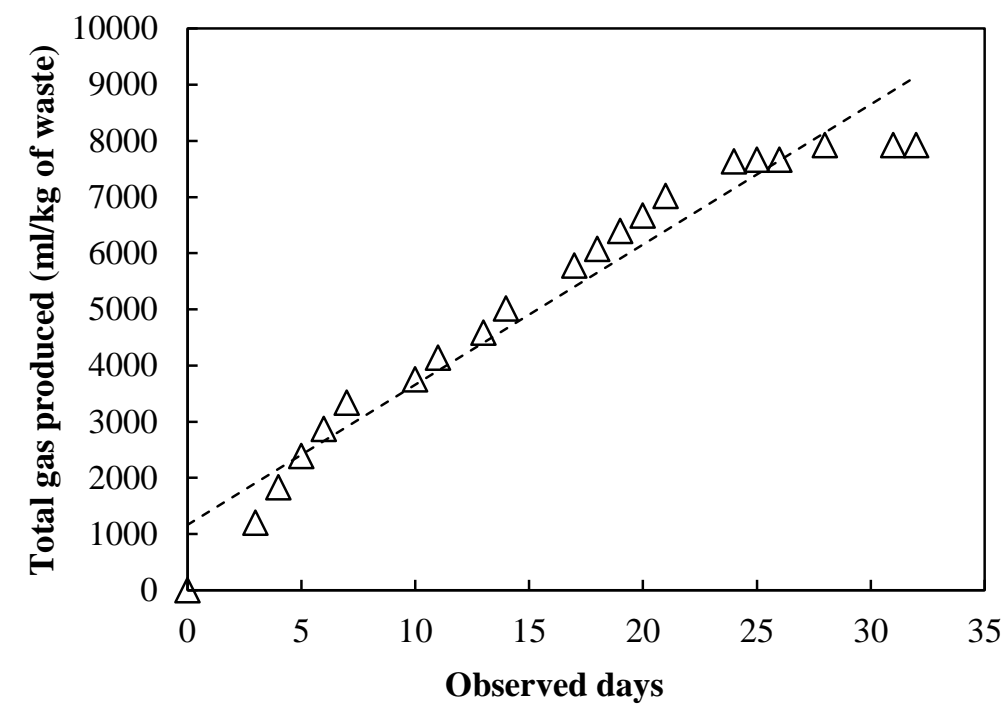

(a) Without silica gel

Total gas produced vs. Observed days (with silica gel)

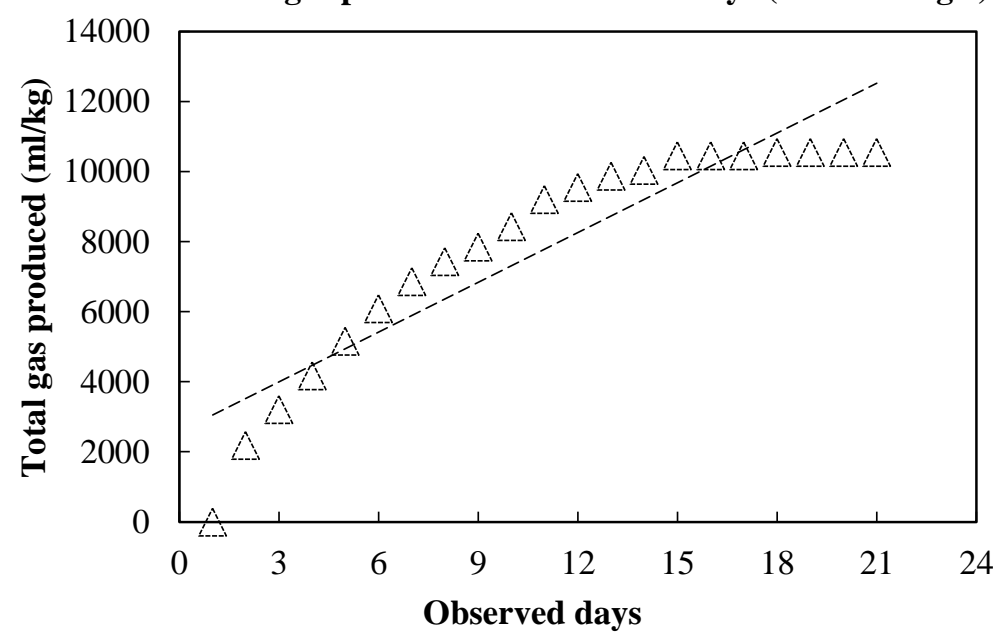

(b) With silica gel

Figure 4. Total gas produced vs. Observed days for the mesophilic digestion of chicken droppings and kitchen waste.

Figure 4(a) shows that the gas production rate increased sharply between the $7^{\text {th }}$ and $24^{\text {th }}$ days. This is because during the period between the setup and initial gas production, the microorganisms responsible for the process were completely inactive [37]. The aerobic bacteria present were using up all the oxygen presents in the digester during this period. After all oxygen has been used up, the acid forming bacteria became active and gas production began. Wangliang, Zhikai [38] also experienced the same rise during their experiment. From Figure 4(b), it can be seen that the gas production was increased between the $3^{\text {rd }}$ and $18^{\text {th }}$ day of observation. The total amount of gas produced was about $8000 \mathrm{ml} / \mathrm{kg}$ using chicken droppings and kitchen wastes. The increase in gas production 
was swift as the number of days increased. However, during the last observation days, the increase in gas production became steady and did not show further increase. The total amount of produced gas was $10545 \mathrm{ml} / \mathrm{kg}$ when the silica gel was used along with the chicken droppings and kitchen wastes. It was $33 \%$ higher compared to the first setup. When the gas production started, the anaerobes present in the organic material became activated and increased in numbers. At the maximum point of production, the anaerobes were acting on the maximum possible amount of the organic materials. After that point, the gas production declined as the excess substrates were converted into methane. There was also a decrease in either carbon or nitrogen available for use [37]. When one comes to an exhaust, the process becomes slower. As it continued, the condition became more appropriate for the methane forming bacteria. Thus, it led to an increase in the percentage composition of methane until the maximum level was reached. As the fermentation approached to the end, the burning characteristics of the gas were improved.

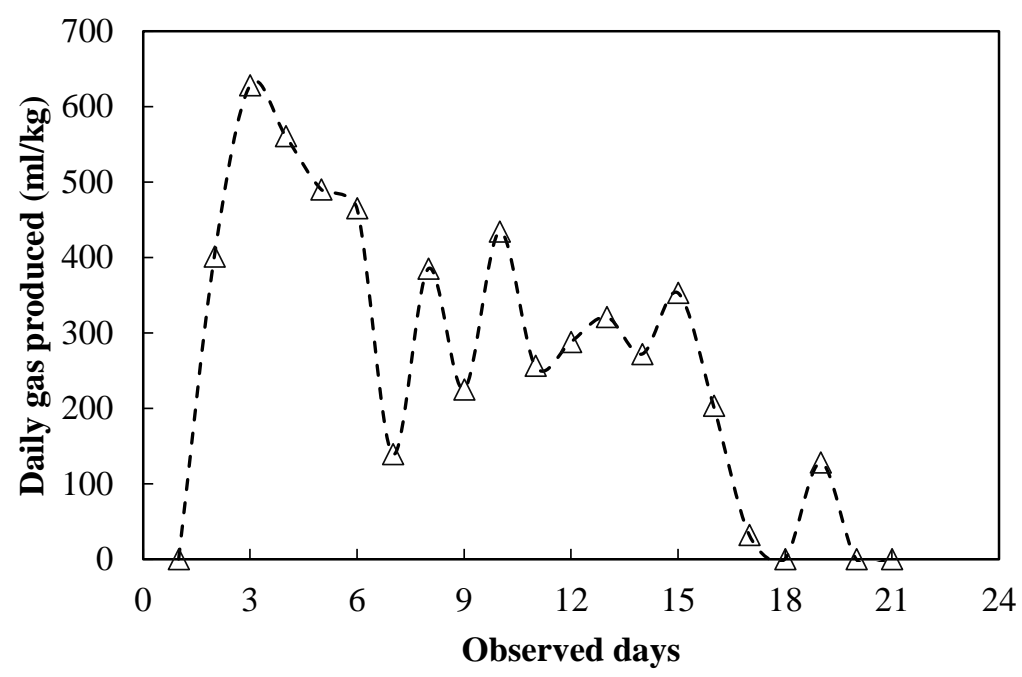

(a) Without silica gel

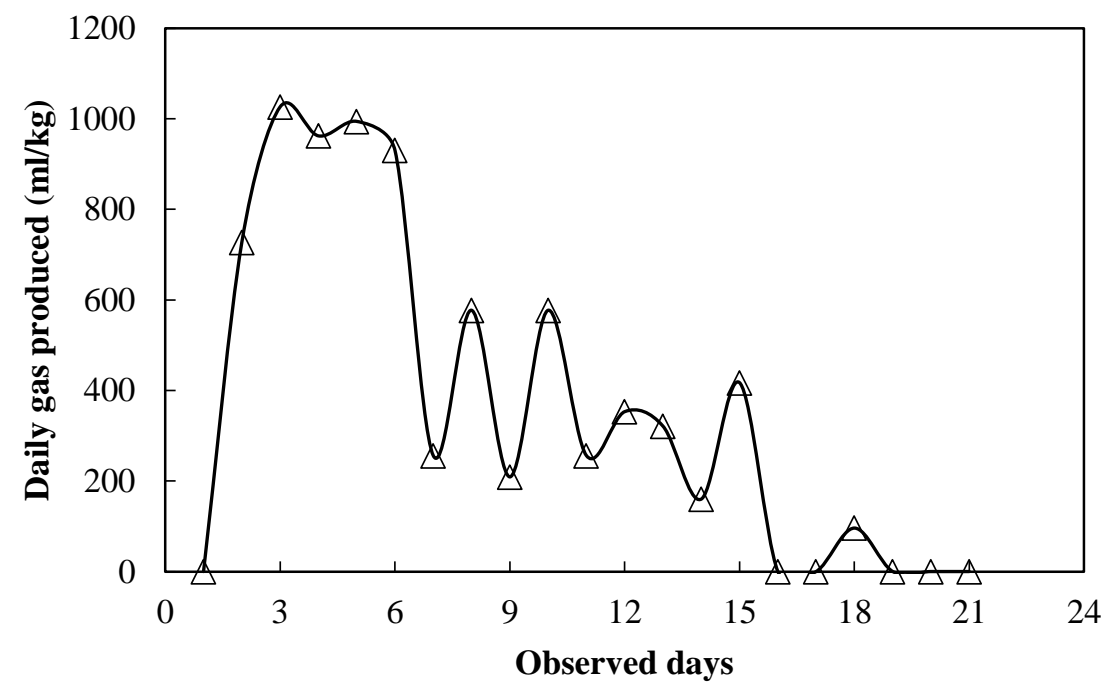

(b) With silica gel

Figure 5. Variation in the daily gas production with respect to the number of observed days during the mesophilic digestion. 
Figure 5 (a) shows the production rate of gas increased up to $628 \mathrm{ml} / \mathrm{kg}$ at first and then started to increase and decrease without maintaining any order. The maximum gas production rate was $628 \mathrm{ml} / \mathrm{kg}$ on the $4^{\text {th }}$ day. The erratic response from gas production was found during the mesophilic disgestion. During the $18^{\text {th }}, 20^{\text {th }}$ and $21^{\text {st }}$ observation days, there was no gas production from the system. On the other hand, Figure 5 (b) depicts that gas production rate that increased between $3^{\text {rd }}$ and $17^{\text {th }}$ day. The total amount of produced gas was $10545 \mathrm{ml} / \mathrm{kg}$ when silica gel was used along with the chicken droppings and kitchen wastes. Figure 5 (b) represents that the production rate was increased up to $1026 \mathrm{ml} / \mathrm{kg}$. Salam, Biswas [9] also reported an increase in the total biogas production rate in his research. They found a daily gas yield of $1244 \mathrm{ml} / \mathrm{kg}$ cow dung with silica gel on the $34^{\text {th }}$ day. The standard as well as expected values vary according to the setup, ambient condition and raw materials. Then the production of gas was increased and decreased without following any order. The maximum gas production rate was found to be $1026 \mathrm{ml} / \mathrm{kg}$ on the $3^{\text {rd }}$ day which was $63.37 \%$ greater than the highest gas production in the $3^{\text {rd }}$ observation day during observation without silica gel.

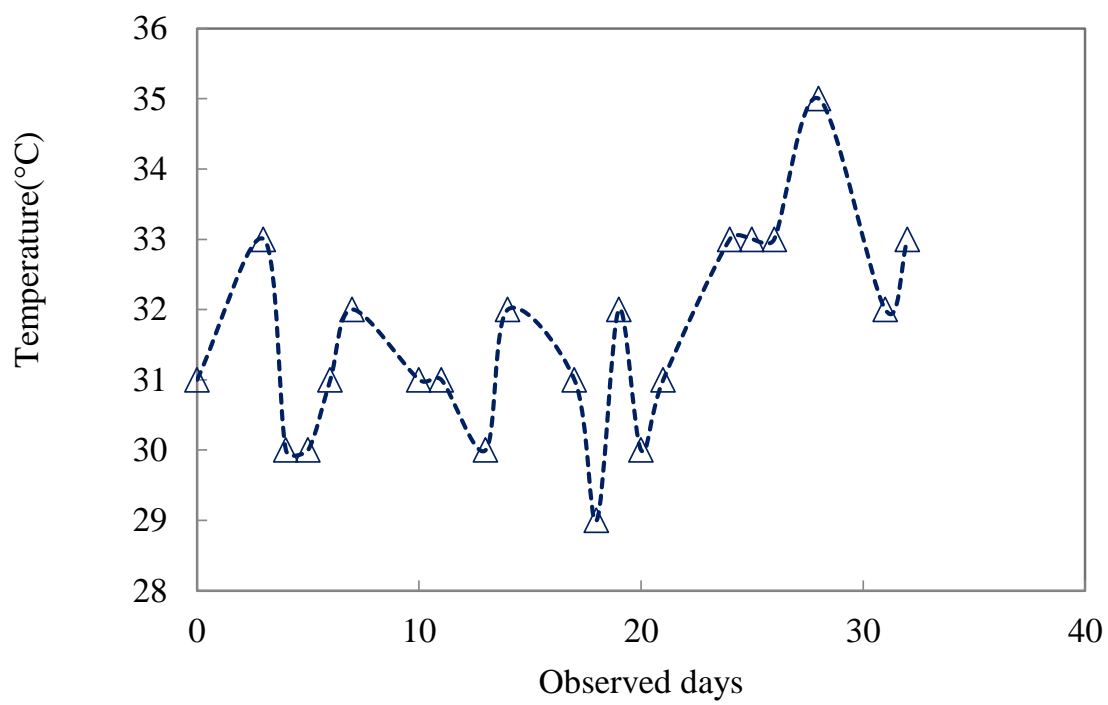

Figure 6. Variation of temperatures $\left({ }^{\circ} \mathrm{C}\right)$ with observed days for the mesophilic digestion.

While tabulating different values, the temperature variation was also observed and the relation with a number of days is plotted below in Figure 6. From Figure 6, it can be seen that the temperatures during this project varies between 29 and $35^{\circ} \mathrm{C}$. Between the $15^{\text {th }}$ and $20^{\text {th }}$ day, the temperature was found to be the lowest. The total gas productions at a lower range of ambient temperatures were found to be significantly lower. At $18^{\circ}$ to $28^{\circ} \mathrm{C}$ ambient temperature range, the total gas productions from two digesters were reported to be 10447 and $13139 \mathrm{ml} / \mathrm{kg}$ cow dung [9][35]. Ukpai and Nnabuchi [30] reported the total gas generation of $7312 \mathrm{ml} / \mathrm{kg} \mathrm{CD}$ from anaerobic digestion of cow dung while slurry temperature was maintained between $22^{\circ} \mathrm{C}$ and $36^{\circ} \mathrm{C}$. In this project, the daily gas yield was found higher when temperature was also high. For example, during the $3^{\text {rd }}$ day of the observation period, the daily gas yield touched the peak point for both setups and the temperature was $33^{\circ} \mathrm{C}$. The daily gas yield found to be relatively lower in a low temperature condition. Garba [39] also found the similar result when conducting 
experiment. He found that the digester kept at $60^{\circ} \mathrm{C}$ produced more gas followed by the digester which was maintained at $40^{\circ} \mathrm{C}$. This could be due to the fact that the methane producing bacteria are not active at this temperature. He also found at $70^{\circ} \mathrm{C}$ temperature, biogas production was very negligible. Thus, an optimum temperature range is always desired and very important for effective biogas generation.

A numerical and graphical comparison was made between two observations. After using the silica gel as a catalyst in the second setup, the gas production rate was found to be higher than the first. The excess amount of gas production was $2624 \mathrm{ml} / \mathrm{kg}$ which is higher than the first observation when only chicken droppings and kitchen waste were used. Figure 7 represents the total gas production rate for both experimental set-ups and it is clearly seen that the gas production was higher for the setup with silica gel than that of without silica gel. It has been reported that the addition of powdered activated carbon results in an increase in the total gas production with high methane content and stabilizes anaerobic process of performance [40]. Similar results were obtained with other adsorbents [41] and [42] studied the effect of silica gel as one of the adsorbents in order to improve the anaerobic codigestion of water hyacinth and cattle dung. Based on the review of literature, it is evident that the adsorbents are responsible for improved digestion. The surface of the adsorbent provides sites where substrate can accumulate thereby providing high localized substrate concentrations. These areas of adsorption provide a more favourable growth environment for the bacterial substrate system. A significant increase of about $33.12 \%$ in the total gas production was observed while using silica gel as a catalyst than the setup without silica gel. Though in the beginning, the difference was not very significant, it became more visible with the increase in a number of days.

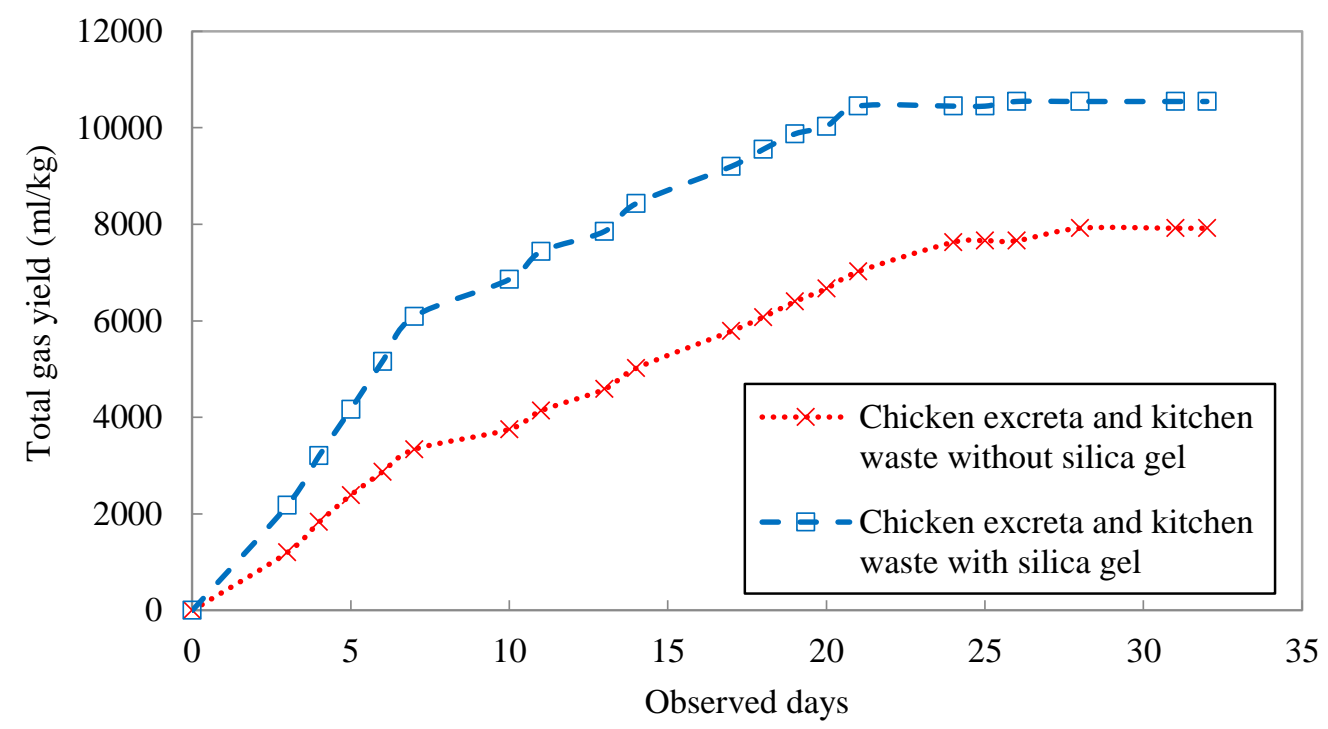

Figure 7. Comparison between two set-ups and effect of catalyst (silica gel) on biogas production.

\section{Determination of flame temperature}

To determine the flame temperature, a k-type thermocouple was used. The type $\mathrm{k}$ thermocouple has a Chromel (Ni-Cr) positive leg and an Alumel (Ni-Al) negative leg. The temperature of the flame was measured around $619^{\circ} \mathrm{C}$. Mandal, Kiran [43] 
determined the quality of biogas by measuring the flame temperature. The highest flame temperature was reached at a value of $685^{\circ} \mathrm{C}$. It was found that the flame temperature increased gradually with the increase in the percentage of methane. In their research work, the flame temperature varied between $600^{\circ} \mathrm{C}$ and $685^{\circ} \mathrm{C}$ for $50 \%$ and $59 \%$ methane content respectively. The feasibility of biogas in combustion has been a key research interest for the researchers and Noor, Wandel [44] performed simulation to study the airfuel ratio for the mixture of biogas and hydrogen for mild combustion. Besides, the effect of air-fuel ratio on temperature distribution and pollutants for biogas mild combustion was also studied by [45].

\section{CONCLUSIONS}

While using poultry droppings and kitchen waste the total gas production was $7921 \mathrm{ml} / \mathrm{kg}$ and the maximum rate was $628 \mathrm{ml} / \mathrm{kg}$ during the mesophilic digestion. For the second set-up which included $5 \mathrm{gm}$ of catalyst (silica gel), the total gas production was found to be $10545 \mathrm{ml} / \mathrm{kg}$ with a maximum production rate of $1026 \mathrm{ml} / \mathrm{kg}$. The total gas production increased up to $33.12 \%$ while using silica gel as catalyst. The effect of temperature was also observed and it was found that the lower temperature of the setup causes a reduction in the gas production whereas a higher temperature is suitable for a better gas production. The flame temperature by using the produced gas was measured and found to be $619^{\circ} \mathrm{C}$. Gas production is not much satisfactory when compared to the optimum values of other organic waste as the volume occupied by the gas is too much. Gas production also depends on continuous feed into the process with a high retention time. From the experimental data, it was found that biogas production was not uniform. From above analysis, it can be said that by this composition it is possible to get the optimum amount of gas production by using a specific catalyst which is silica gel in this case.

\section{ACKNOWLEDGEMENTS}

The authors would like to thank the Department of Mechanical Engineering of Chittagong University of Engineering and Technology for providing space, fund and other necessary materials for the completion of this project.

\section{REFERENCES}

[1] Mladenovska Z, Hartmann H, Kvist T, Sales-Cruz M, Gani R, Ahring BK. Thermal pretreatment of the solid fraction of manure: impact on the biogas reactor performance and microbial community. Water Science and Technology. 2006;53:59-67.

[2] Hinton N, Stone R. Laminar burning velocity measurements of methane and carbon dioxide mixtures (biogas) over wide ranging temperatures and pressures. Fuel. 2014;116:743-50.

[3] Ramasamy D, Zainal Z, Kadirgama K, Briggs HW-G. Effect of dissimilar valve lift on a bi-fuel CNG engine operation. Energy. 2016;112:509-19.

[4] Noor MM, Wandel AP, Yusaf T. The simulation of biogas combustion in a mild burner. Journal of Mechanical Engineering and Sciences. 2014;6:995-1013.

[5] Noor MM, Wandel AP, Yusaf T. Design and development of MILD combustion burner. Journal of Mechanical Engineering and Sciences. 2013;5:662-76. 
[6] Noor MM, Wandel AP, Yusaf T. Analysis of recirculation zone and ignition position of non-premixed bluff-body for biogas MILD combustion. International Journal of Automotive and Mechanical Engineering. 2013;8:1176-86.

[7] Yen H-W, Brune DE. Anaerobic co-digestion of algal sludge and waste paper to produce methane. Bioresource technology. 2007;98:130-4.

[8] Li R, Chen S, Li X, Saifullah Lar J, He Y, Zhu B. Anaerobic codigestion of kitchen waste with cattle manure for biogas production. Energy \& Fuels. 2009;23:22258.

[9] Salam B, Biswas S, Rabbi MS. Biogas from mesophilic anaerobic digestion of cow dung using silica gel as catalyst. Procedia Engineering. 2015;105:652-7.

[10] Leal O, Bolívar C, Ovalles C, García JJ, Espidel Y. Reversible adsorption of carbon dioxide on amine surface-bonded silica gel. Inorganica Chimica Acta. 1995;240:183-9.

[11] Curry N, Pillay P. Biogas prediction and design of a food waste to energy system for the urban environment. Renewable Energy. 2012;41:200-9.

[12] Abubakar B, Ismail N. Anaerobic digestion of cow dung for biogas production. ARPN Journal of Engineering and Applied Sciences. 2012;7:169-72.

[13] Ghani W, Idris A. Preliminary study on biogas production of biogas from municipal solid waste (MSW) leachate. Journal of Engineering Science and Technology. 2009;4:374-80.

[14] Jafari A, Rafiee S, Nosrati M, Almasi F. Investigation yield and energy balances for biogas production from cow and poultry manure. International Journal of Renewable Energy Research. 2014;4:312-20.

[15] Agrahari R, Tiwari G. The production of biogas using kitchen waste. International Journal of Energy Science. 2013;3.

[16] Desai M, Madamwar D. Anaerobic digestion of a mixture of cheese whey, poultry waste and cattle dung: a study of the use of adsorbents to improve digester performance. Environmental Pollution. 1994;86:337-40.

[17] Elango D, Pulikesi M, Baskaralingam P, Ramamurthi V, Sivanesan S. Production of biogas from municipal solid waste with domestic sewage. Journal of Hazardous Materials. 2007;141:301-4.

[18] Isci A, Demirer G. Biogas production potential from cotton wastes. Renewable Energy. 2007;32:750-7.

[19] Karim K, Hoffmann R, Klasson KT, Al-Dahhan M. Anaerobic digestion of animal waste: Effect of mode of mixing. Water research. 2005;39:3597-606.

[20] Kunatsa T. Feasibility Study of Biogas Production from Water Hyacinth. International Journal of Engineering and Technology. 2013;3.

[21] Li R, Chen S, Li X. Anaerobic co-digestion of kitchen waste and cattle manure for methane production. Energy Sources, Part A: Recovery, Utilization, and Environmental Effects. 2009;31:1848-56.

[22] Liu G, Zhang R, El-Mashad HM, Dong R. Effect of feed to inoculum ratios on biogas yields of food and green wastes. Bioresource Technology. 2009;100:51038 .

[23] Obiukwu OO, Nwafor MO. Comparative evaluation of batch and continuous process biogas production from animal wastes. International Journal of Ambient Energy. 2016;37:29-35.

[24] Okeh OC, Onwosi CO, Odibo FJC. Biogas production from rice husks generated from various rice mills in Ebonyi State, Nigeria. Renewable Energy. 2014;62:2048. 
[25] Otaraku IJ, Ogedengbe EV. Biogas production from sawdust waste, cow dung and water hyacinth-effect of sawdust concentration. Intl J of Application or Innovation in Engineering \& Management. 2013;2:91-3.

[26] Owamah H, Alfa M, Dahunsi S. Optimization of biogas from chicken droppings with Cymbopogon citratus. Renewable Energy. 2014;68:366-71.

[27] Quiroga G, Castrillón L, Fernández-Nava Y, Marañón E, Negral L, RodríguezIglesias $\mathrm{J}$, et al. Effect of ultrasound pre-treatment in the anaerobic co-digestion of cattle manure with food waste and sludge. Bioresource technology. 2014;154:74-9.

[28] Recebli Z, Selimli S, Ozkaymak M, Gonc O. Biogas Production from Animal Manure. Journal of Engineering Science and Technology. 2015;10:722-9.

[29] Tripathi AK, Kumari M, Kumar A, Kumar S. Generation of biogas using pine needles as substrate in domestic biogas plant. International Journal of Renewable Energy Research. 2015;5:716-21.

[30] Ukpai P, Nnabuchi M. Comparative study of biogas production from cow dung, cow pea and cassava peeling using 45 litres biogas digester. Advances in Applied Science Research. 2012;3:1864-9.

[31] Shibata K, Kiyoura T, Hayashi Y. Acid property and catalytic activity of silica gel treated with ammonium salts. Journal Of The Research Institute For Catalysis Hokkaido University. 1971;19:29-34.

[32] Singhal V, Rai J. Biogas production from water hyacinth and channel grass used for phytoremediation of industrial effluents. Bioresource Technology. 2003;86:221-5.

[33] Zhong W, Zhang Z, Luo Y, Qiao W, Xiao M, Zhang M. Biogas productivity by co-digesting Taihu blue algae with corn straw as an external carbon source. Bioresource technology. 2012;114:281-6.

[34] Hofmann J, Peltri G, Sträuber H, Müller L, Schumacher B, Müller U, et al. Statistical interpretation of semi-continuous anaerobic digestion experiments on laboratory-scale. Chemical Engineering \& Technology. 2016.

[35] Kreuger E, Nges IA, Björnsson L. Ensiling of crops for biogas production: effects on methane yield and total solids determination. Biotechnology for Biofuels. 2011;4:1.

[36] Miller JN, Miller JC. Statistics and chemometrics for analytical chemistry: Pearson Education; 2005.

[37] Okonkwo UC, Onokpite E, Onokwai AO. Comparative study of the optimal ratio of biogas production from various organic wastes and weeds for digester/restarted digester. Journal of King Saud University-Engineering Sciences. 2016.

[38] Wangliang L, Zhikai Z, Guangwen X. Enhancement of Biogas Yield of Poplar Leaf by High-Solid Codigestion with Swine Manure. Applied Biochemistry and Biotechnology. 2016:1-13.

[39] Garba B. Effect of temperature and retention period on biogas production from lignocellulosic material. Renewable Energy. 1996;9:938-41.

[40] McCONVILLE T, Maier WJ. Use of powdered activated carbon to enhance methane production in sludge digestion. Biotechnol Bioeng Symp;(United States): Univ. of Minnesota, Minneapolis; 1978.

[41] Madamwar D, Mithal B. Effect of pectin on anaerobic digestion of cattle dung. Biotechnology and Bioengineering. 1986;28:624-6.

[42] Patel V, Patel A, Datta M. Effects of adsorbents on anaerobic digestion of water hyacinth-cattle dung. Bioresource Technology. 1992;40:179-81. 
[43] Mandal T, Kiran BA, Mandal N. Determination of the quality of biogas by flame temperature measurement. Energy conversion and management. 1999;40:1225-8.

[44] Noor M, Wandel AP, Yusaf T. Effect of air-fuel ratio on temperature distribution and pollutants for biogas MILD combustion. International Journal of Automotive and Mechanical Engineering. 2014;10:1980-92.

[45] Yamamoto H, Misumi M. Analysis in cyclic combustion Variation in a Lean Operating SI Engine. SAE Technical Paper; 1987. 